\title{
2010년 OECD 동료검토(peer review) - 영국, 독일1)
}

\begin{tabular}{|l|}
\hline \multicolumn{1}{|c|}{ 목차 } \\
I. 개발협력정책의 기본골격 \\
II. 원조 규모, 방식 및 배분 \\
III. 조직과 관리 \\
IV. 원조 효과성 제고 \\
V. 특별 이슈 \\
VI. 인도적 지원
\end{tabular}

$\mathrm{OECD}$ 개발원조위원회(DAC)는 매년 4 5개 회원국들을 대상으로 동료검토를 실시한다. 이는 $\mathrm{OECD}$ $\mathrm{DAC}$ 이 국제사회에서 원조규범을 정하고 이에 대한 준수 여부를 평가하여 사실상의 규범력을 확보하는 수단이자, 각 회원국의 원조의 특징, 모범사례 및 실패사례의 공유를 통하여 회원국간 상호 이해와 상 호 학습을 증진시키는 도구이다. 우리나라는 DAC 가입을 준비하는 과정에서 2008년에 "특별검토 (Special Review)"라는 이름으로 동료검토와 유사한 항목들에 대한 OECD DAC의 심사를 받은 바 있 으며, 2012년에는 OECD 회원국으로서 첫 동료검토를 받게 될 예정이다. 2010년에는 일본, 영국, 독 일, 벨기에, 포루투갈이 동료검토를 받았다. 이 중 영국과 독일의 동료검토 결과를 소개한다. 영국은 원조모범국으로서, 독일은 원조분절화의 문제점에 대한 지적을 통하여 향후 우리나라의 동료검토 대비 및 원조효과성 제고를 위한 노력에 시사점을 제공하고 있다.

동료검토는 크게 개발협력정책의 기본골격, 원조규모와 배분, 조직과 관리, 원조효과성제고를 위한 노 력, 특별이슈(역량개발, 기후변화) 및 인도적 지원 부문으로 구성된다. 각 부문별로 동료검토 결과와 함 께 $\mathrm{OECD} \mathrm{DAC}$ 의 권고(recommendation) 사항이 포함된다.

1) 한국국제협력단 정책기획팀 손송희 직원이 정리 


\section{영 국}

\section{I. 개발협력정책의 기본골격}

\section{1. 법적 정치적 지향점}

1) 글로벌 위기 속에서도 국제적인 개발협력 리더 역할 지속

영국은 개발협력분야에서 리더로 인식되고 있다. 개발원조에 관한 명확한 비전, 일관된 정치적 리 더십, 강력한 인적자원과 재정역량, 그리고 2013년까지 GNI대비 ODA를 0.7\%까지 달성하겠다고 한 공약의 지속적 이행 등에 기인한다. 영국은 원조효과성, 취약국가에 대한 지원, 인도적 지원, 국제사회의 원조시스템의 개혁 등의 중요한 분야에서 주도적인 역할을 하면서, 다른 공여국의 모 델로 평가되며 그 만큼의 책임감을 요구받고 있다.

\section{2) 개발협력분야의 아젠다를 확대하는 동시에 빈곤감소에 대한 초점을 유지}

영국의 개발원조는 “국제개발법(2002)(International Development Act 2002)"의 단일한 법적 근 거를 바탕으로 하고 있다. 이 법은 빈곤감소를 개발원조의 목적으로 명확히 규정하고 있다. 한편 영국은 빈곤감소 외에 새로운 국제적 도전과제들에 대한 대응 노력을 기울이고 있으며 대표적으로 2009년 백서에서는 네 가지 핵심 우선분야를 제시하고 있다. 네 가지 분야는 최빈국의 지속가능 한 성장의 달성, 기후변화에 대응, 분쟁예방 및 취약국 지원, 국제원조시스템의 효율성과 효과성의 강화로 구성된다. 그러나, 이후의 공공서비스협약(Public Service Agreements, PSAs)에서 영국 정부는 개발원조와 관련된 다양한 목표들을 제시하면서 국제개발협력부(Deparment for International Development, DFID)의 우선순위들을 복잡하게 만들고 있다.

영국은 취약국가와 분쟁지역에 대한 지원에 대한 지원의지를 확고히 하고 있다. 취약국에 대한 지 원규모가 지난 5 년간 2 배로 증가하였다. 2009년 백서에 따르면 향후 신규 양자원조의 $50 \%$ 이상 을 취약국의 평화구축 및 국가재건에 지원하기로 하였다. 영국 정부는 또한 평화유지활동, 위기 및 분쟁후 상황에서 취약국에 대한 지원을 위하여 양자원조 뿐 아니라 다자원조를 효과적으로 결 합, 조정할 것을 강조하고 있으며 이 분야에서 $\mathrm{OECD} \mathrm{DAC}$ 이 보다 혁신적인 접근방식을 취하도록 하는데도 기여해왔다.

$\mathrm{DFID}$ 는 수원국과의 정책대화와 원조프로그램에서 양성평등의 촉진을 강조하며 이를 달성하기 위 한 혁신적인 접근법을 모색해왔다. 양성평등의 주류화 노력은 개발의 지속가능성을 달성하기 위하 
여 계속 유지되어야 하며 영국의 모범사례와 교훈을 다른 공여국과 공유할 수 있어야 한다.

\section{3) 국내외적 책임성의 확보}

영국에는 개발원조에 대하여 폭넓은 대중적, 정치적 지지가 있다. 그러나 ODA확대에 대한 대중적 지지는 감소하고 있으며, 원조결과의 효과에 대한 우려가 증가하고 있다. 경제적 위기와 원조 예 산의 감소에 따라 원조 프로그램에 대한 보다 강력한 검토의 필요성이 커지고 있다. 영국 정부는 “UK AID”라는 새로운 로고 개발을 포함하여 다양한 홍보노력과 영국의 원조활동에 대한 결과 공 개 등 원조효과를 보여주기 위한 노력을 기울여왔다.

\section{2. 개발을 위한 정책일관성 제고}

영국은 정부의 모든 대내외적 정책이 개발도상국의 개발 목표를 지원하고 또는 최소한 저해하지 않도록 해야 한다는 점을 강하게 밝히고 있다. 2009년 백서에서는 무역을 포함하여 빈곤감소와 경제성장, 기후변화, 분쟁의 세 가지 핵심 우선분야에 대한 일관성 제고를 위한 계획을 담고 있 다. 영국 정부의 개발을 위한 정책일관성은 두 가지 방식으로 실현되고 있다. 하나는 국제개발부 장관의 내각 및 내각위원회 참여이고 또 다른 하나는 공공서비스협약에서 여러 부처들이 이행해야 할 개발관련 범정부적 목표들을 설정하고 있는 것이다. 실제로 범정부적 접근은 본부와 현장레벨 에서 강화되어 왔으며 특히 무역, 기후변화, 분쟁지역에 대한 지원, 외교정책, 그리고 국방정책 사이의 긴밀한 연계 하에 범정부적 접근 방식을 이행하고 있다.

DFID는 정부 내 관련부처들과 협력을 강화하는데 상당한 진전을 이루어왔다. '국제개발법(2002)' 은 외교, 무역, 기후변화와 국방정책 등이 개발목표와 경합할 경우, 이러한 정책들이 개발목표를 압도하지 않도록 하고 있다. 보다 효과적으로 범정부적으로 개발을 위한 정책일관성을 달성하도록 하기 위하여 DFID는 관련 정책들이 갖는 개발파급효과에 관한 강력한 증거를 타부처에 제시할 수 있도록 노력해야 한다. ‘(보고와 투명성에 관한) 국제개발법(2006)'에서는 DFID가 매년 개발에 대 한 영국 정부의 파급효과를 보고하도록 의무를 부여하고 있으며, DFID는 몇 가지 전략적인 목표 에 있어 개발에 관한 정책일관성에 관한 지표를 포함하고 있다. 그러나 여전히 개발을 위한 정책 일관성을 모니터링하여 대중들과 의회에 보고하는 데 있어 개선의 여지가 있다.

\section{〈권 고〉}

- 개발관련 의제 및 타 부처의 참여 확대 기조속에서도 빈곤감소가 개발원조의 초점이라는 점을 명확히 유지해야 한다. 
- 공공서비스협약 및 백서에서 도출되는 다양한 정책과 목표의 우선순위를 MDGs의 달성을 위한 핵심분야 중심으로 명확히 하여야 한다.

- 영국내 대중적, 정치적 지지를 제고하기 위한 원조 결과의 가시성 추구와 수원국의 우선순위에 대한 지원의 조화를 추구하여, 영국 내 이해관계자들과 수원국에 대한 책임성을 동시에 확보해 야 한다.

- 유럽연합 $(\mathrm{EU})$ 의 정책일관성 정책에 맞추어 새롭게 선정된 분야들에서 영국정부의 개발을 위한 정책일관성을 달성 노력을 기울여야 한다.

- 정부의 다양한 정책이 수원국의 개발에 미치는 파급효과를 측정 및 모니터링하고, 의회와 국민 들에게 효과적으로 보고하여야 한다.

\section{II. 원조 규모, 방식 및 배분}

영국의 ODA 순지출 규모는 2008년에 115 억불로 전년도에 비하여 $25 \%$ 가 증가하였다. GNI 대비 $\mathrm{ODA}$ 비율은 $0.43 \%$ 로서 $\mathrm{DAC}$ 회원국 중 10 위를 차지하였다. 영국 정부는 2013 년까지 ONA/GNI 비율 $0.7 \%$ 달성 목표를 제시해왔고, 2010 년에는 $0.56 \%$ 를 달성할 것으로 예상된다. 영국 정부는 현재 ODA/GNI $0.7 \%$ 달성을 포함한 법초안을 제출하였으며, 이 법이 제정되면 영국의 ODA규모 확대에 대한 신뢰성이 더욱 커질 것이다.

2008 년에 영국 양자 원조의 $63 \%$ 가 수원국의 개발프로그램에 지원되었다. 이는 $\mathrm{DAC}$ 평균 $58 \%$ 보다 높은 수치로서, 영국 정부의 수원국 개발 프로그램에 대한 지원정도와 수원국의 주인의식의 존중 및 원조의 일치(alignment)의 정도를 보여주고 있다.

\section{1. 원조 집중 노력의 중요성}

DFID는 영국 원조의 대부분을 집행하고 있다. 2008년에는 전체 원조의 $86 \%$ 를 DFID에서 집행하 였다. DFID는 양자원조에 있어 선택과 집중의 원칙을 강조하고 있다. 2006년 이래로 23개 국가 에 대하여 양자원조의 $90 \%$ 를 지원하고 있고, 2002년부터 지금까지 36개국에 대하여 사무소를 폐 쇄하거나 지원을 중단하였다. 그러나 영국 원조의 $20 \%$ 가량은 DFID 이외의 부처와 기관에서 분 산되어 집행하고 있고, 정부는 이러한 부분에 대한 원조효과는 제대로 보고하지 않고 있다.

DFID는 양자원조지원 결정을 위한 계량경제학적 모델을 개발하였으나 국별 프로그램을 선택하는 
데 있어 이 모형을 적극 활용하는 것으로는 보이지 않는다. DFID는 주요 이해관계자들에게 대해 국별 프로그램의 선정 기준에 대하여 밝히는 것이 필요하다.

\section{MDGs 달성에 대한 초점과 분야별 지원비중 목표와의 상충}

영국의 양자원조는 MDGs 달성을 목표로 하고 있다. 2008년 양자원조 지원결과를 보면, 저소득 국가(Low income countries, LICs)에 양자원조의 $61 \%$ 를 지원하고, 분야별로는 사회적 인프라와 서비스(social infrastructure and service)에 중점 지원해왔다. 영국 정부는 분야별 지원액 목표 를 설정하고, DFID ODA의 $32 \%$ 가 주로 보건과 교육 분야 등 이러한 목표에 따라서 지출되어 왔 다. 그러나 이러한 분야별 지원 목표는 수원국 정부의 우선순위와 DFID 원조의 일치를 저해할 수 있다는 문제점을 안고 있다.

\section{3. 다자원조 효과성에 대한 긍정적 강조}

2008년 영국 ODA의 $36 \%$ 가 다자원조로 집행되었다. 영국 정부는 다자원조를 통한 효과적 원조 집행에 관한 명확한 계획을 가지고 있다. 2009년 백서에서는 국제원조시스템의 효율성과 효과성 을 강조하고 있고, $\mathrm{DFID}$ 는 다자기구에 대한 지원을 결정할 때 다자기구의 성과를 근거로 하고 있다. 이러한 계획 하에 영국 정부는 UN을 통한 다자원조의 대부분을 정규재원(non-core contribution) 으로 제공하면서도, UN기구의 새로운 성과틀을 제정에 대하여 적극 협의한다. DFID는 다자기구 성과평가 네트워크(Multilateral Organizations Performance Assessment Network, MOPAN)에 적극적으로 참여하고 있으며 그 결과를 $\mathrm{DFID}$ 의 다자기구 성과평가틀로 활용하고 있다. $\mathrm{DFID}$ 는 다자원조를 통해 다른 공여국들과 함께 조화로운 접근법을 촉진할 수 있다.

\section{〈권 고〉}

- 2013년까지 ODA/GNI 비율을 0.7\%까지 확대하기로 한 공약을 성실히 이행하고, 아울러 이를 법제화할 경우 공약 이행의 신뢰성을 높일 수 있을 것으로 보인다.

- $\mathrm{DFID}$ 이외의 부처들이 분산적으로 집행하는 원조에 대한 정보의 질을 향상시키고, 특히 이러한 원조의 파급효과와 돈의 가치(value for money), 일반대중에 대한 정보공개를 강화한다.

- 분야별 지원액 목표 수립을 지양하고, 현재 수립된 분야별 지원액 목표 또한 수원국의 우선순위 와 배치되지 않도록 주의한다.

- 다자원조의 효과성을 높이기 위하여 다른 공여국들과 보다 긴밀하게 협조하고, UN 등 다자기구 의 원조결과와 파급효과를 기준으로 그에 상응하는 지원을 정규재원으로 제공할 필요가 있다. 


\section{III. 조직과 관리}

\section{1. 목표지향적이고 성과지향적인 조직}

영국의 ODA조직은 개발협력의 강력한 모델이 되고 있다. 단일한 부처(DFID)가 영국의 원조정책 수립 및 대부분의 원조 프로그램 집행을 담당하고 있으며, 내각에도 참여하고 있다. DFID는 역량 있고 임무지향적이며 분권화된 조직으로서 원조를 효과적으로 집행한다. DFID는 임원급과 헌신적 이고 유능한 직원들간의 강력한 결합, 본부와 현장 사무소간의 강력한 연계, 부처 내부 및 타 부 처와의 혁신적 협력방식 등의 강점을 보유하고 있다. $\mathrm{DFID}$ 는 조직의 효과성과 효율성을 향상시키 기 위하여 지속적으로 노력하고 있으며 최근 몇 년간 국가 계획 절차(country planning process) 를 강화하였고, 정책수단과 시스템을 개선해오고 있다.

DFID는 운영비가 감소하는 가운데에도 증가하는 원조를 관리해올 수 있었으나 최근에는 적은 비 용으로 많은 원조를 집행하는 데 따르는 전례 없는 어려움에 직면하고 있다. ODA 규모는 2008년 에 비해 2010년에 $11 \%$ 가량 증가할 예정이나 운영예산은 매년 $5 \%$ 씩 감소하고 있다. 또한 취약국가 에 대한 지원을 확대하고 있으나 취약국에 지원에 대한 운영예산이 더 많이 소요된다는 문제가 있 다. 끝으로 이전보다 복잡해지고 분절화된 개발협력 환경 속에서 DFID는 더 복잡하고 광범위한 활동을 담당하고 있다.

DFID는 이러한 과제를 해결하기 위한 개혁을 시도하고 있다. "Making it Happen"이라는 모토 하에 내부적 변화를 시도하고 있다. DFID에 주어진 자원을 가지고 보다 효과성 있게 일하고, 이 를 영국 국민들과 효과적으로 소통하며, DFID가 가진 실증 근거를 보다 효과적으로 활용하는 것 을 기본 골격으로 하며 비용효과성과 돈의 가치 극대화를 추구하고 있다.

\section{2. 역량의 유지 및 강점의 보존}

영국 내 주요 이해관계자들(의회의 국제개발위원회, 감사원 등)은 DFID가 더 적은 운영예산으로 원조의 질을 유지할 수 있는가에 대하여 우려하고 있다. 특히, DFID의 주요 자산인 현장 직원의 수와 전문성을 확보가 어려워질 경우 원조 집행 역량이 위협받게 된다. 따라서 수원국에서 프로그 램의 집행을 담당하는 직원들의 수를 유지하고 전문성의 수준을 유지하는 것이 매우 중요하다. 운 영비를 줄이더라도 취약국을 포함하여 수원국 일선의 직원들을 보존하고 확보하여야 하며, 이를 위한 중기 인력 강화 계획 수립이 긴요하다. 
DFID는 단일한 조직 성과틀을 만들어왔고 연간 프로젝트 리뷰, 2009년 백서 발간, 그리고 여타 정책 우선순위들에 대하여 별개로 보고를 하고 있다. 그 결과 전반적인 보고 틀이 복잡하고, 많은 시간을 요하며, 현장 사무소 직원들에게 중복되는 업무 부담을 주고 있다. DFID는 이러한 상이 한 보고의 흐름들을 어떻게 통합할 수 있을 것인지를 고민해야 한다.

평가에 있어서, DFID는 2007년 5월 '개발 효과에 관한 독립 자문 위원회(Independent Advisory Committee on Development Impact, IACDI)'를 설립함으로써 평가의 독립성을 강화하고, 2009 년 6월에는 포괄적인 평가 정책을 수립하는 등 많은 진전을 이루었다. 이러한 진전들이 DFID에 학습과 성과 문화를 강화하고 성과관리와 기획시스템간 연계 강화에 기여할 수 있어야 할 것이다.

\section{〈권 고〉}

- 단일한 담당부처의 내각 참여, 빈곤감소 임무, 분권화 강화 및 개발 효과성 제고를 위한 역량에 대한 유연한 접근법 등 영국의 강력한 조직 시스템을 유지하여야 한다.

- 개도국 일선 직원의 질과 수를 유지하고, DFID 내에 일정수준의 이상의 전문성, 특히 분야별 전문가들을 확보한다. 이러한 내용을 포함하여 중기 인력 기획 시스템을 개발할 필요가 있다.

- DFID의 보고의무를 간소화하고, 평가 문화를 강화하며, 평가 결과를 관리 도구로 활용한다.

\section{IV. 원조 효과성 제고}

영국 정부는 원조효과성에 관한 핵심 지표들에서 좋은 성과를 보이고 있다. 파리선언의 이행은 DFID의 우선순위로서 DFID는 분권화된 모형과 예산지원 방식의 적극적 활용 등을 통하여 이를 집행하고 있다. 영국의 핵심 이해관계자들은 DFID가 일정한 조건이 만족될 경우 예산지원 방식을 활용하는 것을 지지하고 있으나, DFID는 예산지원이 다른 원조 양식에 비해 가지는 장점을 평가 하고 일반 대중에게 이를 정확히 알리기 위하여 지속적으로 노력해야 한다.

외부의 이해관계자들은 영국이 수원국의 우선순위와의 원조일치, 타 공여국과의 원조조화를 위하 여 많은 노력을 기울이고 있음을 인정한다. DFID는 수원국 내에서 공동국가전략과 성과관리틀 개 발에 리더십을 발휘하고 있다. 그러나 DFID는 유럽연합의 '상보성과 원조분업에 관한 행동강령 (code of conduct on complementarity and division of labour)'에 따라 DFID에 비교우위가 있 는 소수의 분야로 초점을 좁히는 것이 필요하다. 
영국은 중기 예측가능성을 위하여 다양한 조치들을 취해왔다. 현지사무소로 하여금 3 5년 단위의 원조 흐름에 대하여 수원국 정부와 협의하도록 지시하고 있으며, 몇몇 국가들에서는 혁신적인 10 년 단위 개발파트너십협정(Development Partnership Agreements, DPAs)을 체결해왔다. 다만 이 협정내용의 이행 가능성이 높지 않아 보이고, 이러한 협정 체결 자체가 더 많은 국가로 확산되 지 않고 있다.

$\mathrm{DFID}$ 는 조건성(conditionality) 측면에서 많은 개선을 보였다. $\mathrm{DFID}$ 는 정책 조건성(policy conditionality) 의 사용을 제한하는 가이드를 가지고 있다. DFID의 원조조건은 세 가지 파트너십 원칙으로 구성 되며, 빈곤 감소와 $\mathrm{MDGs}$ 달성 추구, 인권과 국제적 의무에 대한 존중, 재무 관리와 재정에 대한 책임성을 강화 등이다. 이러한 원칙의 준수 여부는 수원국의 국가 개발 전략에서 도출된, 상호 합 의된 성과 척도에 따라 평가된다. 그러나 이러한 성과 척도와 파트너십 원칙들간의 명백한 연계가 없는 것으로 보인다.

$\mathrm{OECD} \mathrm{DAC는} \mathrm{영국이} \mathrm{원조효과성에} \mathrm{관한} \mathrm{국제적} \mathrm{대화에} \mathrm{긍정적인} \mathrm{기여를} \mathrm{해왔고,} \mathrm{특히} \mathrm{아크라} \mathrm{행}$ 동의제를 형성하는데 영향력을 미쳐왔다는 점을 인정하고 있다. 최근 몇 년간, 영국은 국제적 원조 투명성 이니셔티브(International Aid Transparency Initiative, IATI), 국제보건파트너십(International Health Partnership, IHP)과 같이 주목을 끄는 이니셔티브에 기여해왔다. 영국은 공여국과 수원 국 정부의 이익을 위하여, 영국의 경험 및 정책수단 등을 공유하여 앞으로도 원조 효과성에 대한 국제적 논의에 지속적으로 기여해 나가야 할 것이다.

\section{V. 특별 이슈}

\section{1. 역량 개발}

영국의 원조정책은 역량개발에 대하여 비교적 전략적으로 접근하고 있으나, 어디에서도 개발협력 의 맥락에서 역량개발에 관한 명백한 비전을 제시하지는 않고 있다.

DFID는 역량을 국가역량(state capacity)과 책임성(accountability) 맥락에서 접근한다. 따라서 국 가계획절차(country planning process)에서 거시적 수준의 역량을 강조해왔다. 그러나 개별 프로그 램이나 프로젝트 수준에서는 이를 설계할 때 역량에 대한 고려가 충분히 이루어지지 않는 한계가 있 다. 또한 영국은 국가역량에 대해 초점을 두기 때문에 정부 부문의 역량개발에 집중하는 경향이 있다. 
DFID는 기술협력에서도 원조효과성 원칙을 도입하고 있다. 기술협력은 다른 원조와 마찬가지로 $100 \%$ 비구속성 원조로 집행된다. 적절한 분야에서는 다른 공여국의 인력풀도 활용하고, 가능한 경우 수원국의 조달시스템을 활용하여 기술협력에 필요한 전문가를 고용한 것을 장려한다.

수원국의 역량개발을 지원하려면 현지사무소에 전문성 확보가 필요하다. 역량개발이니셔티브에 관 하여 수원국과 정책 대화를 실시하고, 필요한 경우 프로젝트나 프로그램에 직접적으로 관여하기 위하여 DFID가 해외사무소에 충분한 전문가를 배치할 필요가 있다.

\section{2. 환경과 기후변화}

정부 고위급의 강한 의지에 따라 영국은 기후변화 대응에 적극 참여하고 있다. 영국 정부는 2008 년에 에너지기후변화부(Department for Energy and Climate Change, DECC)를 신설하였고 '에 너지와 기후변화법(Energy and the Climate Change Act)'을 시행하였으며 기후변화에 관한 공 공서비스협약(PSAs)도 수립하였다. 기후변화는 2009년 백서에서 주요 분야로 명시되어 있다. 공 공서비스협약과 백서의 내용에 따라 DFID는 기후변화의 완화와 적응 수단의 촉진 및 환경적 지속 가능성에 관한 전략적 목표를 세우고 있다. 또한 기후변화 분야의 지식을 향상시키기 위하여 조직 내 기후변화에 관한 연구 역량과 영국의 타 연구기관과의 연계를 구축하고 있다. 기후변화에 관한 프로그램은 아직 초기 단계로서 2008년에 9개 수원국을 대상으로 한 시범사업을 승인하여 실시중 이다. 시범사업으로부터 도출된 교훈을 토대로 DFID는 기후변화와 재해관리를 주류화하는 가이드 라인을 개발하여야 할 것이다.

영국은 국제사회에서 기후변화와 개발을 연계하는데 영향력을 행사하고 있다. 특히, 기후변화에 대한 지원은 “추가" 재원이어야 함을 강조하면서, 기후변화에 대한 지원 확대가 기존의 ODA 공약 을 왜곡시키지 않도록 주의 환기를 강조하고 있다.

기후변화 이외에도 $\mathrm{DFID}$ 는 환경보호를 빈곤 감소에 결정적인 분야로 보고 있다. $\mathrm{OECD} \mathrm{DAC} \mathrm{가}$ 이드라인에 따라, DFID는 전략적환경평가를 이행하기 위한 시스템을 구축해왔다. 특히 2009년 백 서에서 자연재해대응을 위한 지원의 $10 \%$ 를 예방 및 사전대비에 배분하는 것으로 명시하고 있다.

\section{〈권 고〉}

- 수원국이 명확히 인지할 수 있도록 원조 집행과 관련된 모든 조건(conditions)을 공개한다. 또 한 조건이 다른 공여국의 조건과 조화를 이룰 수 있도록 노력해야 한다. 
- 역량 개발과 관련하여 내부적인 커뮤니케이션과 가이드라인을 개선하고, 프로젝트와 프로그램 단계에서 역량개발을 강화하는 방향으로 디자인할 수 있도록 고려한다. 또한 비정부부문에 대한 역량 개발의 지원을 확대한다.

- 수원국의 수요 및 타 공여국에 비하여 영국에 비교우위가 있는 분야 등을 고려하여 환경 분야에 서 보다 폭넒은 이슈에 관심을 기울이는 것이 필요하다. 또한 선택한 분야들에 대한 충분한 전 문성을 확보한다.

\section{VI. 인도적 지원}

영국은 정책과 자금 두 측면에서 국제적인 인도적지원 시스템의 모범생이다. $\mathrm{OECD} \mathrm{DAC} \mathrm{회원국}$ 들 중에서 DFID는 인도적 지원에 3 번째로 많은 지원을 하고 있다. 인도적 지원의 $84 \%$ 를 다자지 원을 통해 제공하며 2007년에는 다자지원을 통한 인도적 지원의 $40 \%$ 가 비지정기여(non-core contribution 또는 core-contribution)로, 24\%가 약한 지정기여(lightly ear-marked contribution) 로 제공되었다. 정규재원 지원금은 다년간 협정을 통하여 지원되어 원조의 예측가능성을 제고하고 있다. 영국은 UN의 인도적 지원 시스템의 개혁을 촉진하는데 두드러진 역할을 하고 있다.

$\mathrm{DFID}$ 는 인도적 지원에 관하여 명백한 전략을 수립하고 있으며, 전략은 선량한 인도적 지원 공여 원칙(principle of Good Humanitarian Donorship, GHD)에 기반하여 예방과 사전대비 및 재건 등 전 과정에 적용하고 있다. 영국은 무장분쟁지역에서의 민간인 보고에 관한 전략(Strategy on the Protection of Civilians in Armed Conflict)도 준비하고 있다. DFID는 국방부와 자연재해 발생시 양 부처의 협력에 관한 양해각서(MOU)를 체결하고 자연재해가 발생하였을 경우 최후의 수단으로서 DFID의 권한 하에 영국의 군자산(military asset)을 활용할 수 있게 된다.

$\mathrm{DFID}$ 는 인도적 지원이 다른 개발 목적에 의해 훼손되지 않도록 잘 관리하고 있으나, 분쟁 또는 취약지역에 있어 평화구축 및 국가 재건 접근 방식, 취약그룹에 대한 특별한 수요, 양성평등과 같 은 범분야 이슈 등과의 연계 및 관계 정립을 보다 명확히 할 필요가 있어 보인다.

\section{〈권 고〉}

- 분쟁 또는 취약지역에 대한 평화 구축 및 국가재건 접근법과 인도적지원의 적절한 혼합전략을 수립한다.

- 인도적 지원활동에 관한 성과틀을 강화한다.

- 인도적 지원의 의사결정 과정에서 다른 이슈들을 어떻게 고려할 것인지를 명확히 할 필요가 있다. 


\section{독 일}

\section{I. 개발협력정책의 기본골격}

\section{1. 법적 정치적 지향점}

1) 세계 최대 공여국으로서 전략적 비전의 쇄신

독일은 지난 20 년간 세계 최대 공여국의 하나로서 기후변화와 개발의 연계와 같은 주요 글로벌이 슈에 있어 리더십을 발휘해왔다. MDGs, 빈곤퇴치 및 원조효과성에 관한 파리선언 등은 지속적으 로 독일의 개발협력정책에서 중시되고 있다. 지난해 연방정부는 독일의 개발협력방향을 대대적으 로 변경할 것이라고 공약하였다. 이 새로운 비전은 2009년 10월 연합 협정(Coalition Agreement of October 2009)에서 윤곽은 잡혔으나 실제 결과는 아직 불분명하다. 연방경제협력개발부(Federal Ministry for Economic Co-operation and Development, BMZ)는 정부가 계획한 방향 변경이 무엇인지, 또한 그것이 지난번 동료검토 이후 공표한 여러가지 공약, 정책 및 전략들에 어떤 영향 을 미칠 것인지를 명확히 밝힐 필요가 있다.

\section{2) 더 나은 성과를 위한 '선택과 집중'}

독일은 2005년 동료검토의 권고에 따라 중점 협력국을 84 개국에서 57 개국으로 줄이고, 57 개 중점 협력국에 대하여 국별전략을 수립하고 있다. 독일은 신흥경제국 중 “주축국”(anchor countries)을 선정하여 이들과의 삼각 협력을 확대하고 있다. 이는 독일이 대외정책과 개발협력 목표를 결합하 여 글로벌 도전과제에 대응하는 혁신적인 접근방식으로 평가된다. 독일은 또한 중점 분야도 11 개 주력분야에 집중하고 있으며, 개별 협력국별로 주력분야들 중 최대 3 개 분야를 선정, 지원한다. 그러나 여전히 독일은 지리적, 분야별 지원 대상이 넓은 편이고 명확한 전략을 보여주지 못하고 있어 보인다. 2009년 10월 이래 독일은 주력분야를 거버넌스, 교육, 보건, 기후·환경 및 천연자 원 보호, 농어촌개발, 민간기업 발전 및 지속가능한 경제발전 등 7 개로 다시 축소하였으나 이 같 은 우선순위 설정이 원조 프로그램과 원조배분에 반영되기까지는 시간이 필요해 보인다. 또한 독 일은 원조 분업 차원에서 중점 지원국가 및 분야를 선정시 다른 공여국들과 협의가 필요하다.

독일이 목표로 설정하고 있는 MDGs와 G7글랜이글스 공약을 이행하기 위하여 BMZ는 사하라이남 아프리카 24 개국을 특별히 중시하고 있으며 교육, 보건, 건전한 거버넌스, 농업, 천연자원 및 수 자원 보호, 지속가능한 경제개발을 중점 지원하고 있다. 향후 독일은 민간부문의 개발로 초점을 확대하는 한편 기후, 에너지를 비롯한 경제 인프라에 대한 투자를 강화하여 아프리카의 경제적 잠 
재력을 확대하고자 하고 있다. 그러나 독일의 원조정책과 재원배분 상에서 사하라이남 아프리카에 대한 지원은 불충분한 상황이며, 특히 사하라이남 아프리카 다수 지역에서 MDGs 달성을 방해하 는 분쟁 및 취약국에 대한 관심이 부족하다.

\section{3) 다자기구에 대한 새로운 전략}

독일은 오랫동안 $\mathrm{ODA}$ 의 최대 $1 / 3$ 만을 $\mathrm{EU}$ 를 포함한 다자적 채널에 할당하는 정책을 유지해왔다. 그러나 이 수치는 명확한 근거 또는 양자 및 다자 원조의 상대적 효과성 비교에 기반하고 있는 것 은 아니다. BMZ는 최근 다자기구를 위한 새로운 전략을 마련하고 있다. 독일의 다자지원 활용의 목적, 다자기구에 대한 재정 지원의 기준 등이 수립될 것으로 보인다. 또한, 새로운 다자 전략은 다자원조를 통한 개발효과에 대한 분석을 포함해야 할 것이다.

\section{4) 양성평등 및 여성의 권리향상에 관한 강력한 리더십 필요}

독일은 정책대화나 원조 프로그램 설계시 양성평등과 여성의 경제적 권리 향상에 힘써왔다. 그러 나 독일의 원조집행기관들이 성주류화를 개별적으로 추진하는 반면, 개발협력체제 전반에서의 젠 더 관련 리더십은 부족한 상황이다. BMZ는 본부와 현장에서 독일의 개발협력 시스템 전반에서 이 문제에 관한 리더십을 발휘하여야 하며, 관련 분야의 역량을 강화해야 한다.

\section{2. 개발을 위한 정책일관성}

1) 범정부차원의 정책일관성 내재화 필요

$\mathrm{BMZ}$ 는 내각에 참여하고 있고 독일의 개발정책수립을 위한 권한을 보유하고 있다. 독일 정부는 정 부의 모든 정책이 협력국의 개발 목표를 지원하거나, 적어도 저해하지 않도록 하는데 주력하고 있 다. 2009년 10 월에 서명한 연합 협정에서도 개발을 위한 정책일관성에 관한 공약을 재확인하고 있다. 그러나 정책 일관성의 이행 여부는 여러 정부부처 내에 이러한 개념을 내재화시키고 이행을 위한 명확한 우선순위를 설정하는 것에 달려있다. 독일 정부는 개발협력을 다른 정책부문에서도 가시적인 목표로 설정함으로써 MDGs 달성에 대한 독일의 기여를 확대해 나갈 수 있는 상당한 여 지가 남아 있다.

\section{2) 정책협력의 장애 제거}

$\mathrm{BMZ}$ 는 다양한 이슈를 효과적으로 감당할 수 있는 자원의 부족으로 정책결정과 정책조정에 관한 영향력과 적극적인 역할의 여지가 적다. 특히, $\mathrm{BMZ}$ 는 타 부처들과 공동노력이 필요한 개발이슈에 관한 분석 및 전략개발역량을 강화해야 하며 동시에, 독일 기타 부처들 내에서 개발 이슈에 대한 
인식과 전문성이 제고되어야 한다.

3) 정책일관성에 관한 모니터링, 분석 및 보고 시스템 강화

독일은 2005년 동료검토 이래로 정책 일관성에 관한 상황을 모니터링, 분석, 보고하는 데 거의 진 전이 없었던 것으로 보인다. 독일은 $\mathrm{OECD}$ 의 정책일관성에 관한 지침서(OECD's Building Blocks for Policy Coherence for Development) 안의 교훈을 참고하여 정책일관성에 관하여 의회와 일 반 대중 등 국내 주요 이해관계자들에 대한 보고 시스템 향상 등 의 개선 노력을 기울여야 한다.

\section{4) 범정부적 접근방식 제고}

독일은 정치적으로 우선순위가 높은 분야, 예를 들어 기후 변화 또는 아프가니스탄에 대한 지원 등에 있어서는 범정부적 접근방식에서 좋은 성과를 냈다. 독일의 이와 같은 경험을 활용하여 여타 글로벌 도전과제들을 해결하기 위한 범정부적 접근방식을 향상시키고 적용할 수 있을 것이다. 독 일은 특히 분쟁 및 취약국가에 대하여 2004년에 도입한 민간인 분쟁 예방, 분쟁 해결 및 분쟁후 평화 재건에 관한 행동계획(action plan on Civilian Crisis Prevention, Conflict Resolution and Post-Conflict Peace-Building)과 같은 공동 접근방식을 확산할 필요가 있다.

\section{〈권 고〉}

- MDGs와 빈곤감소를 달성하기 위하여 개발협력의 명확한 정책을 개발하고, $\mathrm{MDGs}$ 달성을 위하 여 특히 사하라이남 아프리카 지역 및 분쟁 및 취약국가에 대하여 주의를 기울여야 한다.

- 독일의 개발협력 목표를 달성하기 위한 수단으로서 다자기구를 통한 지원 효과의 분석 등을 포 함한 전반적인 다자지원 전략의 수립이 필요하다.

- 개발을 위한 정책일관성 제고를 위한 정책 문서를 마련하고, 정책일관성과 관련하여 개발 목적 의 부처간 우선순위를 분명히 하고 이를 실행하기 위한 계획을 수립한다.

- 정부 내에서 개발을 위한 정책일관성에 대한 책임 부처를 명확히 하고, 정책일관성이 개발에 갖 는 파급효과를 분석하고 전략을 수립할 수 있는 부처의 역량을 구축한다.

\section{II. 원조 규모, 방식 및 배분}

\section{1. 원조 규모 공약의 이행}

2009년에 독일은 전세계적으로 3 번째로 지원규모가 큰 공여국이다. 2009년에 독일이 지원한 ODA 
규모는 120 억달러로 이는 $\mathrm{DAC}$ 회원국 전체 ODA의 $10 \%$ 를 차지한다. 반면, GNI대비 ODA 비율은 $0.35 \%$ 로서, 이는 독일이 제시하는 2010 년 $0.51 \%, 3015$ 년까지 $0.7 \%$ 달성 목표에는 미흡한 수준이다.

독일 정부는 $\mathrm{ODA}$ 규모 확대와 관련, 민간부문개발에 대한 강조가 독일의 상업적 목적에 $\mathrm{ODA}$ 를 활용하는 것으로 변질되지 않도록 주의해야 한다. 즉, 원조 프로그램을 결정하는 기준이 수원국의 개발 효과보다 독일의 상업적 이익이 근거가 되지 않는다는 점을 확실히 해야 한다. 아울러 유상 원조와 관련하여 독일은 유상원조 상환액이 순지출 기준 $\mathrm{ODA}$ 규모를 감소시킬 가능성이 있다는 점 또한 염두에 두어야 한다.

$\mathrm{BMZ}$ 는 독일 $\mathrm{ODA}$ 의 약 $50 \%$ 를 집행하고 있고, 나머지는 다른 정부부처와 기관이 담당한다. 이러 한 특징은 정책일관성을 저해하는 요인으로도 작용한다. 독일은 본부와 현장에서 정책조율을 향상 시킬 필요성이 크며, 중점분야별 지원전략과 가이드라인, 국별지원전략 등이 ODA를 담당하는 모 든 정부부처와 기관에게 적용되어야 한다.

\section{2. 개도국 특히 사하라이남 아프리카에 대한 중점지원 유지}

독일은 중점 협력국의 수를 84 개에서 57 개로 줄였음에도 불구하고, 2008 년에 중점협력국에 대한 지원은 양자 $\mathrm{ODA}$ 의 $40 \%$ 에 불과했고, 나머지 $60 \%$ 는 여타 83 개국에 지원되었다. 또한 2008 년 기 준으로 상위 20 위 안의 수원국 중 비중점 지원대상국이 6 개국이나 포함되어 있다. 따라서 독일은 중점 지원대상국 57 개국에 대한 지원 비중을 늘려야 할 필요가 있다.

특히 $\mathrm{MDgs}$ 달성의 측면에서 사하라이남 아프리카 국가들, 최빈국, 분쟁 및 취약국에 대한 비중을 증가시켜야 한다. 독일의 전체 양자원조 중에서 사하라이남 아프리카 국가에 대한 지원 비중은 2004년 27\%에서 2008년 29\%로 약간 증가하였다. 또한 소득그룹별로는 중소득국가(middle income countries)에 양자 원조를 주로 지원하는 것으로 나타났다. 독일은 스스로 2009년과 2010년에는 전체 양자원조의 $50 \%$ 이상을 사하라이남 아프리카 국가에 지원하겠다고 한 공약과 G7 글렌이글 스의 공약을 이행하기 위해서라도 전세계의 주요 공여국으로서의 책임을 다하기 위하여 더 많은 노력이 필요할 것이다.

\section{3. 부채탕감의 감소}

부채탕감은 몇 년 동안 독일 $\mathrm{ODA}$ 의 주된 방식이었다. 그러나 부채 규모가 감소함에 따라 부채탕 감은 다른 형태의 양자 또는 다자 원조로 전환되고 있다. 2009년에는 부채탕감액 감소가 전체 
$\mathrm{ODA}$ 규모 감소에 영향을 미쳤다. 줄어드는 부채탕감 규모를 다른 원조 방식으로 전환하기 위한 대책의 수립이 필요하다.

\section{NGO에 대한 전략적 접근 필요}

독일은 전체 $\mathrm{ODA}$ 의 $6 \%$ 를 $\mathrm{NGO}$ 를 통하여 집행한다. $\mathrm{NGO}$ 와의 협력에서 독일 정부는 $\mathrm{NGO}$ 에 대한 자율성과 독립성을 중시한다. 그러나 대부분의 $\mathrm{NGO}$ 들이 지원받은 $\mathrm{ODA}$ 예산을 어떻게 지출하는 지에 대한 책임성이 불명확하다. 독일 정부는 $\mathrm{NGO}$ 에 대한 자율성의 존중 뿐 아니라 $\mathrm{NGO}$ 의 활동 이 개발에 미치는 파급효과, 수원국의 개발 우선순위와 일치 정도를 분석하고 보도하도록 해야 한 다. 독일 정부는 $\mathrm{NGO}$ 와의 협약체결 등을 포함하여, $\mathrm{NGO}$ 지원에 대한 체계적이고 전략적인 접근 방식을 택하여야 할 것이다.

\section{〈권 고〉}

- 독일은 2015년까지 GNI대비 ODA비율 0.7\%를 달성하기 위하여 타당한 연간 ODA 목표를 설정 하고, 2015 년까지의 연간 목표를 공개해야 한다. 또한, 부채 규모 감소에 따라 이를 다른 양자 원조 또는 다자원조로의 전환이 필요하다.

- $\mathrm{ODA}$ 지원을 중점 지원대상국에 보다 집중하고, 특히 사하라이남 아프리카 및 분쟁 및 취약국가 에 대한 지원 비중을 늘릴 필요가 있다.

- 민간부문개발에 대한 지원이 수원국의 개발계획상 우선분야에 대한 국내외 투자를 활성화시킬 수 있도록 하는데 집중하고, 특히 민간부문개발에 대한 지원을 통하여 독일의 상업적 이익을 추 구하기 위한 $\mathrm{ODA}$ 활용이 되지 않도록 주의를 기울인다.

- $\mathrm{NGO}$ 에 대한 지원 전략을 수립하고, $\mathrm{NGO}$ 의 활동이 수원국의 개발 목표에 실제로 기여할 수 있 는 방향으로 추진되도록 한다.

\section{III. 조직과 관리}

\section{1. 분절의 완화}

독일 정부는 전반적인 개발협력 시스템은 유지하면서도, 기술협력 집행 기구의 합병, BMZ의 역할 강화 및 부처간의 조율 향상 등 제도적인 개혁을 시도하고 있다. 
$\mathrm{BMZ}$ 는 개발협력정책과 전략 수립을 담당하고 있으나, 집행은 다양한 기구와 타 부처, 연방 주정 부, $\mathrm{NGO}$, 정치적 단체, 교회 등이 실시하고 있다. 독일의 개발협력 시스템의 강점으로는 $\mathrm{BMZ}$ 의 내각 참여와 경험과 전문성을 보유한 집행기관을 들 수 있다. 반면 약점으로는 분절화된 제도를 들 수 있는데, 이점은 2001년과 2005년 두 차례의 동료검토에서도 지적된 바 있다. 독일의 분절 화된 시스템은 수원국에게 혼란을 야기하고, BMZ가 부처와 기관간의 정책을 조율하는데 많은 시 간과 노력이 필요하며, 수요자 위주가 아닌 공급자위주의 원조실시의 위험도 있다.

기술협력과 자금지원 기구들의 분리와 더불어, 독일의 대표적인 기술협력 모델 또한 원조효과성 제고에 걸림돌로 작용한다. 예를 들어 GTZ가 제공하는 현물 방식(aid-in-kind)의 기술협력 모델 은 다른 공여국들과의 조화 및 수원국 시스템 활용을 저해한다. 독일은 계획한 대로 분절화된 시 스템을 개혁해야 하며 첫 단계로 기술협력을 담당기구인 GTZ, DED, InWent을 통합해야 한다. 또한 개혁을 통하여 $\mathrm{BMZ}$ 의 개발협력 정책과 집행 감독권한과 $\mathrm{ODA}$ 전반에 관한 정책 수립의 리 더십을 강화, 기술협력과 자금 협력간의 연계를 강화할 수 있는 효과적인 창의적이고 혁신적인 기 술협력 모델의 채택 등을 실현해 나가야 할 것이다.

\section{2. 분권화의 가속화}

지난 동료검토에서 권고되었던 대로, 독일 정부는 여전히 수원국 현장으로 책임과 권한을 이양할 필요가 있다. 2009년 연합 협정에서 정부는 개발협력 시스템의 현장 시스템을 개선하겠다고 약속 하였다. 현장 시스템 개선은 BMZ의 현지 사무소장의 결정권한 부여 및 정책과 전략수립권한의 행 사를 포함하는 것이어야 한다. 결정권한의 위임 및 적절한 자원의 배분은 독일 정부의 ODA결정 및 승인 절차 지연에 대한 수원국의 불만을 해소하고 독일 $\mathrm{ODA}$ 의 질을 개선할 수 있을 것이다. 아울러, BMZ와 연방대사관간의 업무관계도 개선해야 할 필요가 있다.

$\mathrm{BMZ}$ 는 57 개 중점 협력국 중 38 개국에 사무소가 있다. 원조의 일관성 제고를 위하여 독일은 모든 원조집행기관을 포괄하는 개발협력 해외사무소를 신설하고 공동프로그램을 수립, 집행하도록 할 예정이다. 또한 현장에 중점지역 조정관(focal area co-ordinator)을 임명하여 BMZ가 승인한 사 업에 대한 공동프로그램 설계를 주도하도록 할 예정이다. BMZ는 중점지역 조정관의 권한을 강화 하기 위하여 업무에 필요한 시간의 확보를 포함한 업무 기술서를 작성하고, 재외공관의 개발정책 관에 대하여 보고하도록 하여야 한다. 끝으로 BMZ와 여타 독일 및 수원국의 참여자들과의 역할을 형성하여야 한다. 


\section{3. 평가 시스템의 지속적 향상}

$\mathrm{BMZ}$ 가 평가의 규칙과 규정, 질적 관리와 전략적 평가 등을 담당하고 있지만, 실제로 집행기관들 과 대규모 $\mathrm{NGO}$ 들은 개별적이고 독자적으로 평가를 실시하고 있으며 연간 약 100 여건의 평가 보 고서를 제출하고 있다. BMZ는 독일의 개발협력 평가 시스템을 개선하려 하나 필요한 자원이 불충 분한 것으로 나타났다. $\mathrm{BMZ}$ 는 정부 및 비정부 $\mathrm{ODA}$ 집행기관들이 실시하는 평가의 일관성을 제 고하면서 동시에 그 평가 결과를 활용하여 향후 $\mathrm{ODA}$ 정책 수립 및 집행 의사결정에 환류할 수 있는 시스템으로 개선해 나가야 한다.

\section{〈권 고〉}

- 세 집행기관의 통합이 예정대로 실시될 수 있도록 하고 향후 독일의 전반적인 원조 시스템을 지 속해나가야 한다.

- BMZ가 독일의 원조 정책이 효율적으로 집행되고 있는가에 대하여 범정부적 관리감독 권한을 강화한다.

- 분권화를 향상시키기 위하여 우선 개도국 현지에서 BMZ와 재외공관의 관계를 새롭게 정립해나 가고, 수원국에서 주요지역 조정관의 역할을 개발해나간다.

- 개별 기구와 기관의 독립 평가를 포함하여 평가와 평가결과의 보고 시스템을 향상시킬 수 있도 록 적절한 인적 재정적 자원을 확보하고, BMZ가 평가 결과를 활용하여 원조 프로그램을 향상시 켜 나가도록 노력해야 한다.

\section{IV. 더 나은 원조효과를 위한 노력}

\section{1. 원조 효과성 제고}

\section{1) 2010년 원조효과성 목표 달성을 위한 노력 경주}

독일은 유럽연합을 포함한 국제사회, 독일 국내, 수원국 현지 등 세 영역에서 원조 효과성 제고를 위하여 노력하고 있다. 국제사회에서 독일은 유럽연합 및 $\mathrm{DAC}$ 의 원조효과작업반에서 특히 원조분 업의 촉진을 위하여 주도적인 역할을 하고 있다. 독일 국내 및 수원국 현지에서 BMZ는 원조효과 성에 관한 파리선언 이행을 위한 운영계획을 DAC 회원국 중 최초로 수립하였으며, 2006년에는 원조효과성 매뉴얼을 개발하고, 2006년부터 BMZ 및 원조집행기관을 대상으로 원조효과성에 관한 직원 교육을 실시하고 있다. 
독일은 2006, 2008년 파리선언 설문조사에 참여하였다. 몇몇 지표에서는 이행 여부가 향상되었으 나, 여전히 수원국의 공공재정시스템 및 공동 현지조사 부분에서의 성과가 미미한 것으로 드러났 다. 2009년 운영계획(2009 Plan of Operations)은 수원국의 시스템과 절차를 보다 체계적으로 활용하는 방안을 다루고 있으나 이 분야는 2010년에도 달성가능성이 높지 않아 보인다. 수원국 시스템 활용의 향상을 위하여는 상당한 관리노력이 필요하며 특히 BMZ와 각 집행기관에 파리선 언 이행정도를 모니터링할 수 있는 담당자를 지정하는 것도 고려해볼 수 있다.

\section{2) 비구속성 원조 비율 확대}

2008년에 DAC 회원국의 양자원조 비구속성 원조비율은 평균 $81 \%$, 기술협력에 대한 비구속성 원 조비율은 $61 \%$ 였다. 독일은 양자원조에서 $77 \%$, 기술협력에 대하여는 $41 \%$ 를 비구속성 원조로 집행 하여 전체 및 기술협력에 있어 DAC 평균보다 낮은 수치를 보였다. 파리선언 및 아크라행동계획을 달성하기 위하여 독일은 비구속성 원조 확대 일정을 포함, 신뢰할 수 있는 계획을 수립해야 한다.

\section{2. 특별 이슈}

\section{1) 역량 개발}

역량 개발은 지난 수년간 독일 개발협력의 주요 목표였다. 역량개발을 위하여 기술협력을 주요 수 단으로 활용해왔다. 초기에는 주로 개인 및 현지조직의 역량강화를 위한 기술이전에 초점을 맞추 고 있었으나 최근에는 점차 거시적으로 입법, 경제, 사회, 환경 및 정치적 맥락에서의 역량강화로 초점이 이동하고 있다. 하지만 놀랍게도 독일은 개발협력에서 역량 개발에 관한 명확한 정의도, 전략도 수립되어 있지 않다. BMZ는 역량 개발에 관한 개념을 명확히 정의해야 하고, 아울러 기술 협력이 어떻게 다른 원조 수단 및 도구들과 효과적으로 연계될 수 있을지를 모색하고, 프로그램접 근법이나 부문별 또는 일반 예산지원 방식 등으로의 활용에 대한 고려가 필요하다. 또한 독일은 또한 분쟁 및 취약상황에서 역량 개발의 원칙들과 기술협력이 국가 재건(state building)에 더 잘 기여할 수 있도록 실용적인 가이드라인을 제시해야 한다.

독일은 집행기관간의 합병을 통하여 기술협력을 수원국이 주도하는 역량개발을 위한 도구로 새롭 게 고안해야 한다. 이러한 기관개혁은 기술협력을 위한 전문가 선정과 평가에 수원국의 참여를 확 대해야 한다. 개혁을 통하여 기술협력 집행기관이 수원국의 역량 개발을 최우선시 하고, 적절한 모니터링과 평가 메커니즘을 구축해야 한다. 아울러 독일은 기술협력이 독일 국내 노동시장이나 국내의 역량에 위협이 되지 않도록 명심해야 한다. 
독일은 기술협력에 있어 다른 공여국들과의 조율을 향상시키고 있다. 2007년에는 독일 기술협력 지원의 $73 \%$ 가 다른 공여국들와 조화를 이룬 것이었으며, 독일은 기술협력풀(technical assistance pools) 등을 통하여 원조 조화 개선을 추구해나가고 있다. BMZ와 GTZ는 기술협력풀에 관한 가이드 라인을 준비하고 있다. 여기서 강조되어야 할 점은 수원국이 수요 및 기술협력이 필요한 분야를 스 스로 결정하고 기술 서비스를 선택, 계약 및 활용할 수 있는 역량을 배양하도록 해야 한다는 점이다.

\section{2) 환경과 기후변화}

독일은 환경과 기후변화 분야에서 강력한 범정부적이고 국제적인 리더십을 발휘해왔다. 2008년에 비해 2009년 독일 ODA에서 환경 및 기후변화 관련 지출이 $40 \%$ 증가하였다. 환경과 기후변화 분 야는 강력한 고위급의 정치적 의지가 뒷받침되고 있으며 독일의 환경 및 기후변화에 관한 법과 전 략틀 또한 개도국의 기후변화 대응 지원의 중요성을 강조하고 있다. 독일은 산림벌채 및 침식 등 에서 비롯되는 탄소 방출량을 줄임으로써 기후변화의 완화와 적응을 지원하는 프로그램(reducing emission from deforestation and degradation, REDD)을 신속히 시작하는 등 환경 및 기후변화 분야에서 국제사회에 약속한 사항들을 이행해야 할 것이다.

$\mathrm{BMZ}$ 와 연방 환경자원보존원자력안전부(BMU)간의 파트너십은 기후변화 분야의 중요한 특징이자 개발을 위한 정책일관성을 좋은 사례이다. 이 파트너십의 중심에 $\mathrm{BMU}$ 의 국제기후이니셔티브 (International Climate Initiative, ICI)에 필요한 재원을 탄소배출거래권을 통하여 조달하는 방 식이 있다. 이 독특한 재정 조달 방식은 국제적인 기후 협상 과정에서 혁신적인 자금조달방식의 모델을 보여준다. 한편 독일은 또한 수원국의 녹색성장을 촉진할 수 있는 국가개발계획을 주류화 할 수 있도록 환경과 기후변화 분야에서의 수원국의 역량개발까지 지원을 확대해 나가야 한다.

독일은 이 분야에서 대체로 $\mathrm{DAC}$ 의 가이드라인을 따르고 있으며 지난 20 여년 동안 환경을 원조 프로그램에 주류화하기 위한 강력한 조치들을 추진해왔다. 2009년 중반부터 기후변화 이슈는 새 로운 프로젝트와 프로그램에 적용되는 “Climate Check"를 통하여 독일의 원조에 적용되었다. 독 일은 기후와 개발에 관한 행동프로그램(Programme of Action on Climate and Development)을 가이드라인으로 활용하고 있으며 최근에는 Climate Check와 환경영향평가, 전략적환경평가의 통 합을 시도하고 있다. 통합이후의 새로운 “공동 환경 기후 평가"는 전략 수립 및 개별 프로그램과 프로젝트 수준에 공통적으로 적용될 예정이다.

\section{〈권 고〉}

- 원조효과성 제고를 위하여 수원국 시스템의 활용을 확대하고, 수원국의 주인의식을 극대화할 수 있는 프로그램 접근법 등을 적극적으로 실시한다. 
- 기술협력 분야에서 비구속성 원조 비율을 확대하고, 기술협력이 수원국의 수요와 수원국의 시스 템에 보다 적합하도록 운영한다.

- 기술협력에 대한 전반적인 전략을 수립하고 특히 취약국가의 국가 재건에 기술협력이 기여할 수 있는 방안을 포함시킨다.

- 환경 및 기후변화 분야에서 독일이 약속한 공약들을 이행하고, 환경 및 기후변화 분야에서 리더 십을 지속적으로 발휘한다.

\section{V. 인도적 지원}

\section{1. 인도적 지원의 정책 수립}

독일은 아직까지 인도적 지원에 관하여 범정부적 정책이나 가이드라인이 없다. 독일의 비교우위가 있는 분야에 초점을 맞춘 거시적인 정책을 수립함으로써 각 부처간의 역할을 보다 효과적으로 분 담하고, 긴급구호와 장기 재건프로그램 간의 연계를 촉진시킬 수 있다. 또한 수원국을 위하여 보 다 포괄적인 모니터링 시스템과 책임성의 확보가 가능해질 것이다.

\section{2. 인도적 지원 재정 확대}

$\mathrm{OECD} \mathrm{DAC}$ 의 인도적 지원 비중은 2008년에 9.2\%이나, 독일은 $3.3 \%$ 에 불과하다. 전세계 적 주요 공여국의 하나로서 독일은 향후 인도적 지원 비중을 보다 확대해 나가야 한다.

\section{3. 원조 분업의 명확화 및 부문간 연계 강화}

독일은 연방해외사무소(Federal Foreign Office)에서 긴급지원을 제공하고, BMZ는 재해복구를 지 원한다. 인도적 지원 조정 위원회(Humanitarian Aid Coordinating Committee)에서 BMZ와 연방 해외사무소, 여타 인도적 지원 참여자들간의 조율을 담당하고 있다. 그러나 위원회의 활동에도 불 구하고 관련 정부부처간 역할분담을 보다 명확히 하고, 연방해외 사무소의 인도적 지원 담당자와 $\mathrm{BMZ}$ 의 전문가 간의 협력을 강화해야 할 필요성이 크다. 일례로 현재 재해위험감소(disaster risk reduction, DRR) 프로그램은 연방해외사무소와 BMZ로부터 자금을 지원받지만, 일관된 감독 체계 와 담당자들간의 공적 연계가 없다. 또한 이러한 분절은 수원국 입장에서 거래비용을 증가시키는 데, 예를 들어 이러한 불편은 수원국 정부가 단일한 목적을 가진 프로젝트를 서로 다른 기관에 서 
로 다른 제안서와 가이드라인의 적용을 받는데 기인한다. 아울러, 연방해외사무소의 신속한 자금 지원은 긴급재해발생에 대처하기 위한 필요성은 인정되나 단기 프로젝트로서 선량한 인도적지원 공여원칙(Good Humanitarian Donorship)의 원칙, 특히 유연한 운영과 장기 재건에 대한 지원 원칙을 훼손할 우려가 있다.

\section{〈권 고〉}

- 독일은 다양한 원조 수단 중에서 독일에 비교우위가 있는 분야에 초점을 맞추어 인도적 지원에 대한 전반적인 정책을 수립하고, 구호 및 개발 프로그램간의 연계를 강화해야 한다. 아울러 인 도적지원의 규모를 지속적으로 증가시켜야 한다.

- 독일은 인도적 지원에 있어 BMZ와 연방 해외 사무소간의 역할을 명확히 구분하고, 수원국이 단 일한 제안서와 보고 시스템을 활용할 수 있게 하며, 아울러 정부 및 시민사회에서 인도적 지원 을 담당하는 주체들과의 연계도 강화해야 한다. 